\title{
ARTÍCULOS
}

\section{REVIEW OF NATIONAL AND INTERNATIONAL INITIATIVES ON BOOKS AND BOOK PUBLISHERS ASSESSMENT}

\section{Revisión de iniciativas nacionales e internacionales sobre evaluación de libros y editoriales}

\section{Elea Giménez-Toledo, Jorge Mañana-Rodríguez, and Carlos-Miguel Tejada-Artigas}

Nota: Este artículo puede leerse traducido al español en:

http://www.elprofesionaldelainformacion.com/contenidos/2015/nov/02_esp.pdf
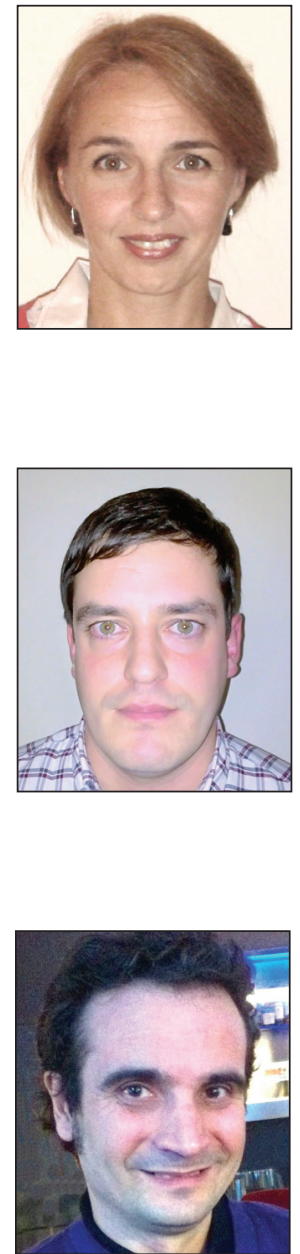

Carlos-Miguel Tejada-Artigas, PhD in Information Science, is a tenured lecturer at the School of Information and Library Sciences at Universidad Complutense de Madrid. He is a member of the ÍlIA research group and coauthor of Scholarly Publishers' Indicators.

http://ilia.cchs.csic.es/SPI

http://orcid.org/0000-0002-2767-5636

Universidad Complutense de Madrid, Facultad de Ciencias de la Documentación Santísima Trinidad, 37. 28010 Madrid, España cmtejada@ucm.es

\section{Abstract}

This article presents various systems for assessing academic books and/or book publishers in several European countries and two in Latin America. It has been structured according to the methodologies used in each system: expert opinion, reviews, holdings in academic libraries, specialization, original selection procedures, citations, and systems integrating different variables. The objective is to offer a panoramic view for evaluators, authors, librarians, and editors to use in decision making. Also included are conclusions about various assessment systems, their potential, and the optimum conditions for their use in practice. 


\section{Keywords}

Book assessment; Academic book publishers; Academic monographs; Quality indicators; Humanities and social sciences; Scientific assessment.

\section{Resumen}

Se presentan varios sistemas de evaluación de libros y/o editoriales científicas en varios países europeos y dos latinoamericanos con las metodologías que aplican: opinión de expertos, reseñas, presencia en bibliotecas académicas, especialización, sistemas de selección de originales, citas y sistemas integradores de variables. Con ello se ofrece una visión panorámica que permitirá a los evaluadores, autores, bibliotecarios y editores contar con información para tomar decisiones. Las conclusiones son útiles para utilizar diferentes sistemas de evaluación, sus potencialidades y las condiciones óptimas de uso en la práctica.

\section{Palabras clave}

Evaluación de libros; Editoriales académicas; Monografías académicas; Indicadores de calidad; Humanidades y ciencias sociales; Evaluación científica.

Giménez-Toledo, Elea; Mañana-Rodríguez, Jorge; Tejada-Artigas, Carlos-Miguel (2015). “Review of national and international initiatives on books and book publishers assessment". El profesional de la información, v. 24, n. 6, pp. 705-716.

http://dx.doi.org/10.3145/epi.2015.nov.02

\section{Introduction}

It is undisputed that books are an important communication channel for Humanities and Social Sciences scholars. Books dominate in the scientific output in these fields. According to Rectors Conference of Spanish Universities (CRUE), 14\% of the publications in the Arts and Humanities, from all Spanish University lecturers and researchers in 2010, were books, and $42 \%$ of the publications were book chapters (Michavila, 2012). The importance of books can also be seen when looking at citation rates: between 75 and $80 \%$ of the documents cited by Literature scholars are books (Stern, 1983), while in the case of Arts (Cullars, 1992) and Philosophy (Cullars, 1998) this percentage ranges between 60 and $85 \%$. In the UK about one-third of the documents published in Social Sciences and Humanities are books (Kousha; Thelwall; Rezaie, 2011). In light of these data a question should asked regarding the importance of books in these fields: Why are they important? And the answer is simple: books offer researchers in Social Sciences and Humanities features which journal articles do not (Domingo-Baguer, 2013; GiménezToledo; Tejada-Artigas; Mañana-Rodríguez, 2013).

\section{Books dominate in the scientific output of Humanities and Social Sciences}

Assessments of scientific output have traditionally been limited to the analysis of scientific journals and are the focus of researchers in the fields of bibliometrics and scientific assessment. However, books have received little research attention and are, therefore, a pending task to further the assessment efforts in Social Sciences and Humanities. When books are left out of assessment efforts it deepens the marginalization of books as a mode of scholarly communication currently fundamental in the Social Sciences and Humanities.

The Norwegian system Cristin may be considered the first experience regarding books evaluation since it included a categorization for the assessment of books published by the scholarly community of Norway. In 2011 two other sources of indicators for books were presented. During the 13th International Society for Scientometrics and Informetrics (ISSI) Conference, the Book Citation Index was publicly announced and launched (Adams; Testa, 2011). At the same time, the first ranking of book publishers based on the opinions of humanists and social scientists was launched in Spain (Giménez-Toledo, 2011); this first ranking eventually became Scholarly Publishers' Indicators (SPI).

\section{The assessment models in Europe tend} to be more qualitative

From then up to the present a series of advances in the research have taken place. Also, several information systems and indicators for the categorization of books and book publishers have been developed in Spain and other European and Latin American Countries. The review of all the experiences in this field permits a better knowledge of the assessment processes and its uses and also the identification of their chronology and evolution, the background positions of each initiative and the acceptance of these systems by the different scholarly communities. http://www.cristin.no/english

\section{Assessment of books and book publishers}

International and national sources of indicators (such as Web of Science, Scopus, and ERIH) aimed at assessing journals have existed for decades. However, it is only recently that indicators for assessing books have been proposed.

Following the previously established path of citation-based metrics, both Thomson Reuters (Book Citation Index) and Scopus (Book Titles Expansion Program) developed their own tools for books. Nevertheless, their limited language coverage (basically restricted to English) and the citation-based indi- 
cators (which are based on their own information systems) do not offer a proper assessment for the needs of social scientists and humanists, where books are a primary element.

It is remarkable that the Research Excellence Framework $(R E F, U K)$--the most important research evaluation process in UK-- does not use citation metrics when performing assessment exercises ${ }^{1}$. It is also important to note that the assessment models in Europe (including Spain) tend to be more qualitative.

Due to the absence of information systems that assess books and monographs, some European countries have developed their own individual information systems, which are used as support in the assessment of research activity.

\section{Objectives}

This work aims to offer a comprehensive review of the initiatives and methodologies used in various European countries (and two in Latin American) to assess books and/or book publishers. It is also an objective of this work to underline the clear and substantive differences between the assessment systems, as well as showing the diversity of existing approaches regarding the study of books and book publishers.

This wide-scope review provides those with responsibilities in scientific assessment a general overview on current practices which will help in decision making. This review might also be useful for researchers selecting book publishers, scholars who want to establish the book as legitimate research output, and academic librarians in book selection.

\section{Methodology}

The experiences and information systems reviewed in this article have been identified through an exhaustive literature review, as well as by means of information exchange and scientific collaboration with some of the researchers who have responsibilities in the management of these systems. The participation of the authors in the European network EvalHum and several international meetings on the assessment of Social Sciences and Humanities have been crucial in preparing this review.

http://www.licorn-ubs.com/evalhum

Once the systems and experiences were identified, a literature review was carried out and included websites and working documents regarding each information system.

\subsection{Book assessment methodologies}

Taxonomy of book assessment methodologies

The studies and projects analyzed in this review can be classified according to several variables. The axis of this taxonomy is the following:

a) Their stage: it is possible to find

- partial and empirical studies which in- volve the application of some indicators on book publishers of one or more disciplines;

- 'complete' information systems, which offer one or more indicators applied to a full set of book publishers belonging to a range of disciplines and that can be applied, therefore, to large sets of scientific output.

b) Their developers:

- public developers: governmental institutions, research groups, etc.;

- private developers: Thomson Reuters, Elsevier, etc.

c) The 'product' type generated by the assessment systems:

- book publishers' categorizations;

- quality labels;

- rankings;

- systems which compile diverse indicators for each book publisher.

d) Geographical reach: in general, it can be stated that all systems show or can reach international audiences since these systems include book publishers from all over the world (those in which the researchers have published).

e) Methodological approach: it is possible to identify:

- qualitative methodologies: expert opinion, analyses of book publishing processes, specialization, review analysis; - quantitative methodologies; citations.

5. Results. Review of the assessment models for books and / or book publishers

\subsection{Expert opinion-based assessment systems}

\section{Current Research Information System in Norway (Cristin)} http://www.cristin.no/english

Cristin is a Norwegian database that keeps an exhaustive record of all the publications authored by researchers affi-

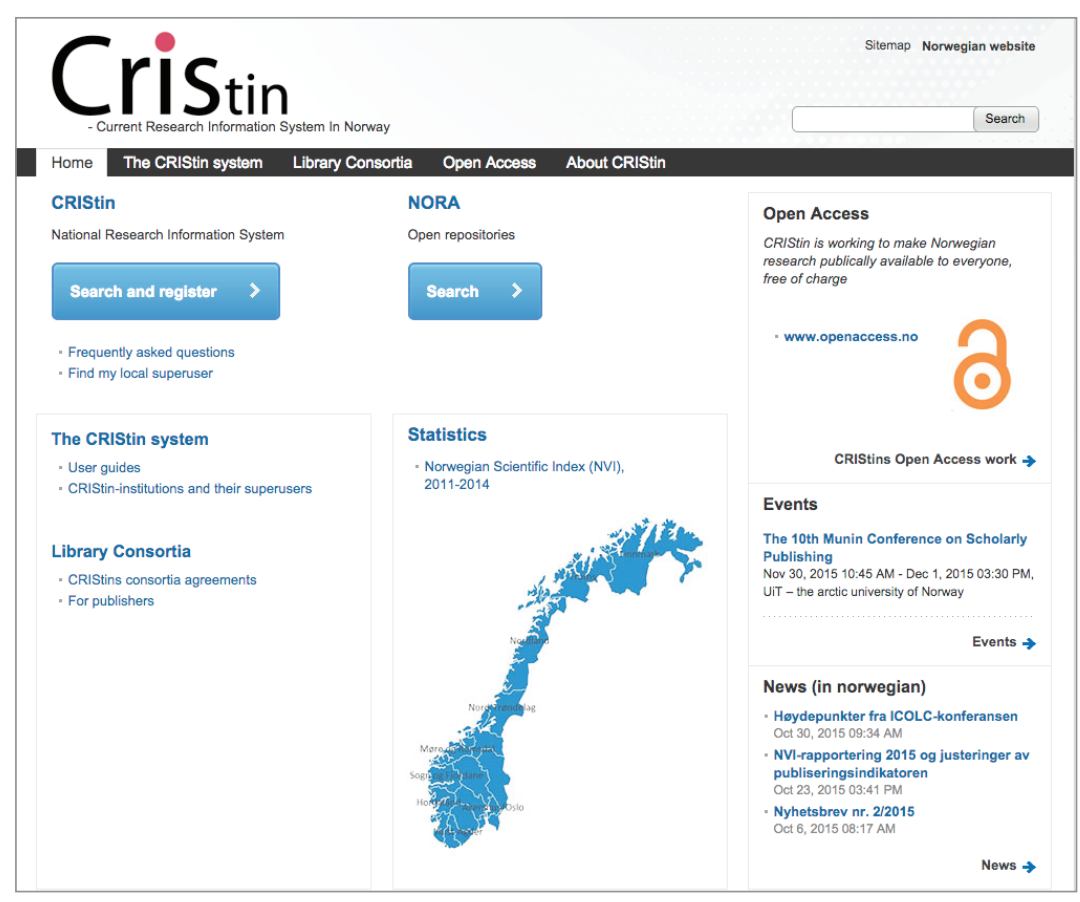

Figure 1. Current Research Information System in Norway (Cristin) http://www.cristin.no/english 
liated to universities and the public sector's research carried out in Norway. It is, therefore, a unified database which contains all metadata required for further analysis taking into account field-specific issues. Both academic journals and book publishers are classified in two categories or levels ( 1 and 2 ) by disciplinary panels conformed by researchers in various institutions in the country; the two levels are reviewed annually by the National Councils in each discipline, together with the National Publishing Board. This system operates with two aggregation levels: first, the individual records of each publication and second, the level regarding the communication channels (for example, mainly book publishers and journals).

The Norwegian model has also been adopted in Denmark, Flanders, Finland and Portugal

Regarding scholarly books and monographs, the classification system is applied at the level of book publisher. The proportion of these documents is determined by a panels of experts so that only $20 \%$ of book publishers are at the higher evaluative value (2) while $80 \%$ fall into the lower category (1). Scores given to documents in each level range from 8 points, for a book published in a level 2 book publisher, to 0.7 in the case of a book chapter in a level 1 book publisher. Regarding journal articles, the maximum score given to a scientific paper published in a level 2 journal is 3 points. According to its methodology, the system can be described as qualitative (Sivertsen, 2010, p. 26) since final quantification $^{2}$ (belonging to one of the two levels numerically quantified) has a mere denominative aim: the judgments leading to the classification are exclusively qualitative. Citations are not taken into account as an information source. Also the assignation of maximum and minimum scores within each category cannot be considered a quantitative system: that quantification is instrumental and is entirely based on qualitative judgments.

Although the Norwegian model was specifically designed for the assessment of publications authored by Norwegian researchers, the core scheme has also been adopted in Denmark (Ingwersen; Larsen, 2014), Flanders, and Finland (Auranen; Pölönen, 2012). The system keeps its core structure but has been adapted to the specific needs of each country. While the results of the specific Norwegian lists are closely attached to the practices of the Norwegian scholarly community, the method has also been implemented in Portugal (Sivertsen, 2014).

\section{Scholarly Publishers Indicator (SPI) http://ilia.cchs.csic.es/SPI}

Scholarly Publishers' Indicators (SPI) is an information system on book publishers developed by the Research Group on Scholarly Books (ÍLIA) at the Spanish National Research Council (CSIC). This system has the general aim of offering different visions -through indicators- on scientific / scholarly book publishers (both Spanish and non-Spanish). The quality indicators offered for each book publisher are intended to inform authors and evaluators about some of the key features of the book publisher so they can count with objective judgment elements in the assessment process. The system does not have among its aims the 'automation' of the assessments of scientific output in the form of books, but instead it offers information in order to clarify, complete, or support an evaluator while making a judgment.

The four elements around which SPI has been developed are:

1) The prestige perceived by the academic community towards specific book publishers.

This prestige has been identified through two large surveys sent to Spanish lecturers and researchers in all fields of the Humanities and Social Sciences. The 2012 and 2014 editions of the survey were sent to over 11,000 scholars. Response rates $(26 \%$ and $23.05 \%$ respectively) can be considered high for this type of studies and, although there is variance among the disciplines, the results show a gradation of perceived book publishers' prestige in each field and prestige concentration in a core of book publishers. The number of 'mentions' for each book publisher as well as the position in which they have been voted are included in the data for the calculation of the book publishers' prestige indicator (Giménez-Toledo; TejadaArtigas; Mañana-Rodríguez, 2013). This indicator has enabled the construction both disciplinary and general rankings for all the fields studied.

Figure 2. Scholarly Publishers Indicators (SPI)

http://ilia.cchs.csic.es/SPI 
2) Book publishers' thematic specialization.

Knowing the disciplinary profile of a book publisher (including the disciplines in which it has published the largest amount of titles or in which disciplines its production has been more stable over time) gives an idea about its relevance and position in a given field. Specialization is highly regarded in scholarly publishing and it is required, not only in research itself, but also in the selection of publication channels. In order to better understand the specialization of Spanish book publishers, data from Dilve (Distributor of Information on Spanish Books for Sale) were analyzed. The result of these analyses is a series of charts reflecting the distribution of titles through disciplines for each book publisher.

http://ilia.cchs.csic.es/SPI/especializacion_editoriales_spi.html

SPI offers information in order to clarify, complete, or support an evaluator while making a judgment

Book publishers' specialization is among the features taken into account by assessment agencies in their criteria (Aneca, 2008; p. 22) and is also considered by Aneca (Spanish National Agency for Quality Assessment and Accreditation in Spain) as a plausible variable for the improvement of university presses' competitiveness (Unelibros, 2014).

3) Original manuscript selection process.

SPI has progressively included more information regarding the original manuscript selection process of scholarly book publishers. Both evaluators and readers expect the texts have been reviewed or validated by experts in the field.

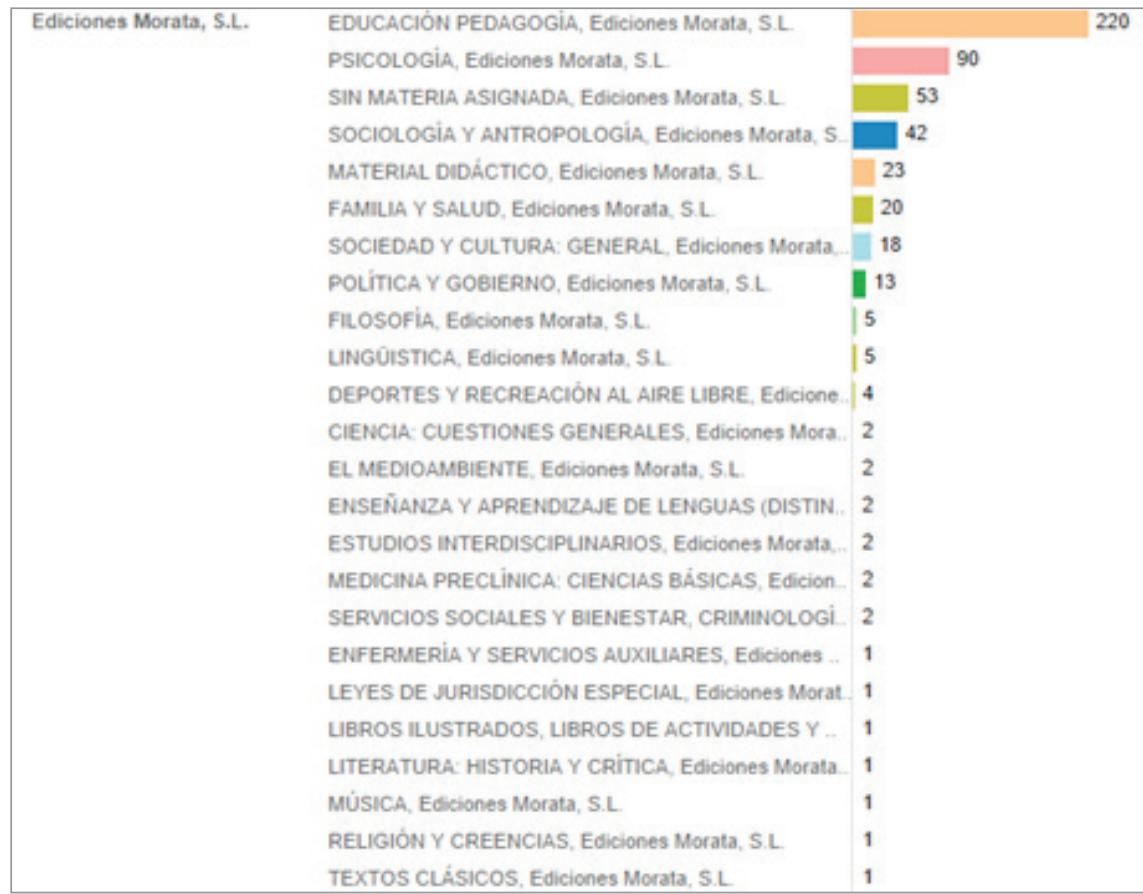

Figure 3. Example of book publisher disciplinary profile. Distribution of titles among disciplines for Ediciones Morata.

http://ilia.cchs.csic.es/SPI/especializacion_editoriales_spi.html
Guidelines from the evaluation agencies often highlight this variable; however, this information can only be provided by book publishers and it is usually not publicly disclosed (Giménez-Toledo et al., 2014).

4) Presence of book publishers in other information systems.

SPI Expanded offers information about book publishers in four international information systems.

http://ilia.cchs.csic.es/SPI/expanded_index.html

One of the systems is SPI; the other information systems are the Book Citation Index (Thomson Reuters), Scopus (Elsevier), and the lists of publishers from the Norwegian model (see previous section).

These three systems were selected for inclusion for several reasons. First, they include the information usually mentioned by assessment agencies when reviewing book publishers. Also, previous studies involving researchers and publishers (Giménez-Toledo; Tejada-Artigas; Mañana-Rodríguez, 2013; ÍLIA, 2014; ÍLIA, 2015) have shown the role of these indicators as 'highly definitory' of the quality of a book publisher. This reflects a high degree of consensus on the issue and makes these indicators more adequate than others, both for the features pointed out earlier and for their acceptability.

\subsection{Reviews}

Although the studies regarding book reviews are scarce (Hartley, 2006, among them), Zuccala and Van-Leeuwen (2011) have analyzed the role of this type of document in citation networks traceable in the Web of Science (in the case of History and Literature), showing the potential relevance of these documents in assessment procedures in those fields for which books are the main communication channel.

Zuccala et al. (2015) have recently carried out an altmetric approach in the case of History books (cited in a set of journals identified in Scopus). They analyzed the correlation between the scores obtained in the open valuation site Goodreads and the citations received by the books. These correlations were positive but weak, which, notwithstanding any further causal relationship, shows the limited covariance of both variables. http://www.goodreads.com

\subsection{Presence in academic libra- ries}

An analysis of academic library holdings enables the identification of frequently indexed book publishers. This information then helps to identify higher or lower interest from academic libraries. This is related to the interests of the users of the 
library. This technique is known as Library catalog analysis (LCA) or Libcitations (White et al., 2009). It provides information on the visibility of book publishers in libraries. Currently, studies related to library holdings of book publishers are limited to specific disciplines (Torres-Salinas; Moed, 2009) and/or analyze library catalogs in specific countries. The relationship between holdings and citation counts has been analyzed by Zuccala and Guns, 2013. In general terms, the comparisons with other metrics do not show similar results and the difficulties while identifying large groups of titles (apart from the initial experimental actions) could compromise the extensive feasibility of this methodology. Book purchasing in academic libraries is not limited to research monographs -lecturing manuals also appear in library holdings and this is a limitation of this technique, which would measure the holdings of non-scholarly books in university libraries.

\section{Libcitations provides information on the visibility of book publishers in libraries}

\section{Book publishers' library metrics (BPLM)}

http://www.librarymetricsforbookpublishers.infoec3.es/ layout. php?id=acerca

This product was developed by the EC3 research group at Granada University. Its aim is to measure the diffusion of books published by different book publishers in libraries according to their presence in Network of Spanish Academic Libraries (Rebiun). BPLM includes Social Sciences and the Humanities and offers data on the number of documents, number of documents included in Rebiun, and the average number of inclusions for the various disciplines in Social Sciences and Humanities (only for the first quartile of the most productive publishers). The set of book publishers included in BPLM are those previously identified in Scholarly Publishers Indicators (SPI).

\subsection{Specialization}

Thematic specialization of book publishers is an important variable (similarly to the case of scholarly journals, MañanaRodríguez, 2013). This variable reveals a deeper and more detailed understanding of the publishers' activity.

Since 2014, in the case of SPI (see previous section) information processed from Dilve (Distribuidor de Información del Libro Español en Venta) has been analyzed and published, and included in an analysis of over 500,000 individual books which tied each title to a main topic and book publisher. From that information it has been possible to recodify the subject categories into fields. These analyses revealed a thematic specialization for book publishers that are highly specialized in a given discipline.

\subsection{Peer review}

Apart from being one of the objects of analysis of Scholarly Publishers Indicators (SPI) (see previous section), peer review is the axis of the quality label created in Flanders and also the core variable of the Registro Nacional de Editoriales de Colombia (National Registry of Colombian Publishers).

\section{Quality label for peer reviewed books (Flanders)}

The key role of peer review is as an assessment process which guarantees the quality and rigor of what is finally published (Hames, 2008). Nevertheless, in the case of books the various modalities, procedures, and objectives of publishing has a wide disparity in the criteria and formalization levels (as well as the application) of peer review systems (Derricourt, 2012). Taking into account the relevance of the existence of such systems in the case of books, the Publishers Association of Flanders created a label for peer reviewed books (the Guaranteed peer reviewed content, $G P R C$ ) in the context of the regional system of assessment for scientific publications (PRFS) through the Vaab-shw (Engels; Ossenblok; Spruyt, 2012; Verleysen; Engels, 2013). https://www.ecoom.be/en/vabb

In the case of books there is a wide disparity in the criteria, formalization, and application of peer review

This system includes an initial core of 82 publishers (118 in 2013) which were selected in an assessment process in Norway. Books requesting the label must provide a specific set of documents to prove the peer review process has taken place. This label has been assigned to 51 books in 2011 and 43 in the second half of 2012. The label is a registered trademark (Benelux trademark No. 0916696) and has two purposes: the first is to create a 'reactive effect' which hopefully leads to the adoption of peer review by other publishers and the second is to provide useful information regarding the assessment process.

\section{National Registry of Colombian Publishers (Colciencias)}

Colciencias, the Colombian institution in charge of the promotion of research and development, created the National Registry of Colombian Publishers with the objective of 'keeping record of the book publishers which guarantee the scientific quality and editorial quality of those books published as a result of research' (Colciencias, 2013). Although there was a call for inclusion in the system in 2013-2014 very few publishers were accepted. The project seems to be stuck, possibly as a result of controversy among university presses.

\section{http://goo.gl/oT54P1}

Publishers must have procedures for tracking the publishing process and be able to provide proof of their publishing process. Among these criteria is the requirement of independent peer review. Finally, a 'publishing evaluation report' is required, in addition to the basic publishing norms (legal deposit, ISBN, contents tables, etc.)

\subsection{Citations}

Book Citation Index $(\mathrm{BCI})$ (and derived products such as $\mathrm{Bi}$ publishers)

The public reveal of Book Citation Index in 2011 (Adams; Testa, 2011) introduced Thomson Reuters into the market of metrics for scholarly books. Book Citation Index is a licensed system which offers information on citations for 
books from approximately 500 book publishers. The selection of books covered is based on citations received from a core of documents. Also, although $\mathrm{BCl}$ indexes books in languages other than English, the product explicitly declares that books published in English will be given preference (Testa, 2012). This has important implications regarding its usability (Torres-Salinas; Delgado-López-Cózar, 2013). An expert panel selects book publishers, ultimately placing responsibility of integrity onto the book publisher':

'As with journals, a peer review process is also associated with scholarly books, and Thomson Reuters relies on the integrity of the publisher to insure that book content is valid and original.' (Testa, 2012, p. 2).

From a methodological perspective, $\mathrm{BCl}$ has a combination of qualitative and quantitative criteria: value judgments are combined with citation counts (which can be understood as quantitative or pseudo-quantitative according to Nijkamp, Rietveld and Sperdijk, 2000). Also, although the product is commercial, the obvious biases towards books published in English combined with other elements of the selection process (the citation analysis prior to the indexation of books traced in a core of presumably Anglo-Saxon origin) reveal a remarkable limitation with regards to its potential use with evaluative aims. These limitations, both in their coverage and their selection process, have been the object of detailed analyses in previous works (Gorraiz; Purnell; Glänzel, 2013; Torres-Salinas et al., 2012).

The quality of the contents of the book is a factor frequently mentioned by humanities' scholars as one of the key elements for the assessment

One of the developments directly derived from Book $\mathrm{Ci}$ tation Index is the Bipublishers project (Torres-Salinas et al., s. d.), which was developed by EC3 research group at Granada University. This project has the aim of analyzing 'the research performance and scientific publishers included in the Book Citation Index' through citation analysis in order to analyze their impact. Its experimental orientation is clearly stated, . The product includes six indicators, structured in three dimensions: output (total number of books and total number of book chapters), impact (total number of citations and field normalized citation counts) and profile (activity index and percentage of edited items).

\section{Scopus Book Titles Expansion Program}

The announcement of the Scopus Book Title Expansion Program in 2013 involved an important change in the coverage policy the Scopus database with regards to scholarly books. http://www.elsevier.com/about/press-releases/scienceand-technology/elsevier-announces-its-scopus-book-titlesexpansion-program

Originally the database included 7,500 books and by 2015 it had 75,000.

http://blog.scopus.com/topics/books

The selection procedure starts with publishers and suggestions on individual book titles are not accepted. The selection criteria is generically described on their website:

- reputation and impact of the publisher;

- size and subject area of the books' list;

- availability and format of the book content;

- publication policy and editorial mission;

- quality of published book content.

http://www.elsevier.com/online-tools/scopus/contentoverview\#content-policy-and-selection

Two of the selection criteria are particularly important. One is the publishing mission, which may be different between university presses and commercial book publishers. Another is the quality of the contents of the book; this factor is frequently mentioned by humanities' scholars as one of the key elements for the assessment of the quality of their publications. However, establishing quality is as subjective and unfeasible due to high costs, both in money and time. Although the calculation is not straightforward, the number of hours needed to assess the quality of the content of 75,000 books seems to be overwhelming. At least it seems overwhelming for a selection committee made up of 14 members (Content Selection and Advisory Board, CSAB). Some of these specialists have assessment functions on fields as diverse as psychology, stomatology, and veterinary sciences.

http://www.elsevier.com/online-tools/scopus/contentoverview\#scopus-content-selection-and-advisory-board 
The use of citations for the development of book publishers' rankings, taking Scopus as the source of information, was first used in the work of Zuccala et al. (2014), with a low correlation. This is also the case with correlations between citations received by books referenced in documents indexed in Scopus and WorldCat libcitations (Zuccala; Guns, 2013); the highest correlation was 0.288 for History and Literature \& Literary Theory between 2007 and 2011 which does not diminish, by any means, the importance of the results.

\section{Google Scholar as a source of citations for books and Pu- blisher Scholar Metrics}

The traditional sources of citation metrics in scientific journals at the international level (Web of Science / Journal Citation Reports and Scopus) share space with a third source of information which is being extensively explored, also in the case of books: Google Scholar and Google Books (Kousha; Thelwall, 2015; Abdullah; Thelwall, 2014). The complementary nature of Google Scholar with respect to the databases from Thomson Reuters seems clear when citations from books using Google Scholar include between 31\% and 212\% of citations registered in the Web of Science (Kousha; TheIwall, 2009).

\section{Google Scholar is important for its huge} coverage, the constant gathering of data and rate of updating and, therefore, the timeliness of its metrics

Also, the development of methods for the depuration of the results (mainly, deduplication) from Google Books facilitates data gathering and derived calculations on citations from and to books (Kousha; Thelwall, 2015). The use of the information provided by Google Scholar regarding citations received by books, once grouped according to their publisher, has been the object of analysis in Spain through the development of Publishers Scholar Metrics by the research group $E C 3$, a system in which citations received by publishers in which Spanish scholars have published are considered. In order to develop the product, a set of highly cited books (7,203 books) was identified, from which the volume of citations from publishers was extrapolated.

http://www.publishers-scholarmetrics.info

Regarding the place of Google Scholar, now or in the near future, as a source of indicators, it is important to mention its huge coverage, the constant gathering of data and rate of updating and, therefore, the timeliness of its metrics (citations and h-index). Also, it is relevant to consider the cautions required for its use in relation to the possibility of data manipulation (Delgado-López-Cózar; Robison-García; Torres Salinas, 2014), the opacity of the system (Van-Leeuwen, 2014), and the difficulties of its traceability.

http://www.ref.ac.uk/about/guidance/citationdata/ googlescholar/\#d.en. 78940

\subsection{Systems integrating several variables}

Apart from SPI (already described), it is important to mention the quality label initiative Academic Publishing
Quality $(A P Q)$ which has been promoted by Unión de Editoriales Universitarias Españolas (UNE) and designed by three Spanish research groups:

- Electra from Salamanca University;
- EC3 from Granada University, and
- ÍLIA from panish National Research Council (CSIC).

The Spanish University Publishers Union has promoted the quality label Academic Publishing Quality

This initiative aims to provide recognition of best practices in the publication of scholarly book series (none of previously discussed analyses have focused on book series). The quality label includes twelve quality indicators of a book series plus an additional indicator: the internationality level of the book series. The indicators take into account various variables involved in the publishing process, such as the adequacy of the scholars in charge to the series profile, the type of technical and electronic edition, its visibility, etc. (Unelibros, 2015). This evaluation model does not aim to assess all existing scholarly book series, but only those series that request an assessment. It is a label, but not an assessment system.

A second assessment process applied to books (but not to book series nor publishers) is the one carried out in Brazil by Coordenação de Aperfeiçoamento de Pessoal de Nível Superior (Capes), which is a foundation attached to the Ministry of Education for the development of postgraduate education in the country. The initiative, called Roteiro para Classificação de Livros has, as its main objective, to formulate indicative indicators for the assessment of scientific output in book format in the case of postgraduate programs and are, 'therefore, inadequate for the individual assessment of lecturers, researchers, and students' (Capes, 2009). In the assessment process, both scope and content are analyzed: relevance, innovation, and diffusion potential or impact is taken into account. After this, additional information is added: the book being reissued, institutional support, translations, fit between the content and the research profile of the author, editorial committee and peer review and, finally, awards that have been given to the title. In the assessment process, several scores are given to each variable and one of these variables is the book publisher. It is important to note different scores exist between commercial and university presses, national and foreign publishers, and national and international distribution channels.

\section{Discussion and conclusions}

The analysis of the initiatives regarding the assessment of books and book publishers shows variety in the methodological approaches, contexts, and motivations for the design of assessment models as well as differences in the aggregation level considered (books, collections, or book publishers).

In light of the results of this review and as was concluded in a recent comparison at the European level (GiménezToledo et al., 2015), there is a predominance of qualitati- 
ve approaches in the assessment models. The qualitative methods are often created and promoted by institutions, research groups, and publishers' associations while the quantitative methods are most often developed by database producers and based on citation counts.

The newer initiatives for evaluating books, book series, or book publishers are often experimental in nature, but represent positive changes and support for these works within academia. There exist differences in the degree of implementation: the categorization of the "Norwegian system" is applied directly to institutional assessment processes; $S P I$ is used as support or orientation in some panels of assessment of research activity in Spain (España, 2014); the quality seal for book series promoted by UNE could be used in future evaluation processes; and other methodologies, such as those based on book reviews or libcitations, are still being explored and cannot yet be used systematically in evaluation processes.

The information offered by different systems and studies is not only useful for evaluation purposes, but can be very interesting for both authors, who provide the scholarly works to publishers, and for publishers, since they have a "mirror" where they view themselves and obtain information for their own improvement and for comparison with other publishers.

\section{Neither Book Citation Index nor Scopus Book Title Expansion Titles are currently being used for assessment purposes in Europe}

Also relevant is the fact that neither the Book Citation Index nor Scopus Book Title Expansion Titles are currently being used for assessment purposes as a source of information in any of the European systems reviewed. This fact might be related to the biases which were already identified in the case of scholarly journals (predominance of English, predominance of publications from certain disciplines, and from specific countries) or perhaps it is an indicator of an emerging movement in the assessment of scientific output in which the value of citations is relativized (see Leiden manifesto, Hicks et al., 2015). Above all, it is characterized for the use of qualitative approaches such as the announced by Aneca (España, 2015). Nevertheless, when using citations for book publishers as an indicator in the assessment process, Google Scholar seems to be the most popular because data sets are more complete when compared to publishers. However, the lack of transparency in Google Scholar is remarkable. A further limitation of Google Scholar is that the citations received by humanities books are far from immediate.

Finally, it is important to mention that the set of reviewed works described here is useful in assessment processes because they offer information about the different nature of books and book publishers and permit the assessment procedures carried out on universities, departments, and researchers to be more comparable and objective. Taking these things into account, care must be taken in the use of these tools, and it is advisable to combine them for a qualitative judgment. It is also important to remember that these assessment tools might also affect the publishing sector which implies caution in their use.

\section{Notes}

1. "The subpanels within the Main panel D will neither receive nor make use of any citation or bibliometric data to inform their judgements" (Panel D is one that integrates the Humanities disciplines).

http://www.ref.ac.uk/media/ref/content/pub/panelcriteria andworkingmethods/01_12_2D.pdf

2. Numeric does not equal quantitative (Agresti, 2013), both concepts are confused (particularly in the case of citation: Sandström; Sandström, 2009).

\section{References}

Abdullah, Abrizah; Thelwall, Mike (2014). "Can the impact of non-Western academic books be measured? An investigation of Google Books and Google Scholar for Malaysia". Journal of the American Society for Information Science and Technology, v. 65, n. 12, pp. 2498-2508.

http://www.scit.wlv.ac.uk/ cm1993/papers/Univ_Press_ Books_preprintx.pdf

http://dx.doi.org/10.1002/asi.23145

Adams, Jonathan; Testa, James (2011). "Thomson Reuters Book Citation Index". In: Noyons, Ed; Ngulube, Patrick; Leta, Jacqueline (eds.). Proceedings of ISSI 2011: $13^{\text {th }}$ conf of the Int/ Society for Scientometrics and Informetrics, Durban, South Africa, July 4-7, 2011. Durban, South Africa: ISSI; Leiden University; University of Zululand, v. 1, pp. 13-18, ISBN: 9789081752701

Agresti, Alan (2013). Categorical data analysis. New York: John Wiley \& Sons, ISBN: 9780470463635

Aneca (2008). Principios y orientaciones para la aplicación de los criterios de evaluación. Madrid: Aneca

http://www.aneca.es/content/download/10527/118089/ version/1/file/academia_14_ppiosyorientaciones.pdf

Auranen, Otto; Pölönen, Janne (2012). Classification of scientific publication channels: Final report of the Publication forum project (2010-2012). Helsinki: Federation of Finnish Learned Societies, ISBN 9789525995046 https://www.tsv.fi/julkaisufoorumi/materiaalit/publication_ forum_project_final_report.pdf

Book Publishers Library Metrics (2015). http://www.librarymetricsforbookpublishers.infoec3.es/ layout.php?id=inicio

Capes (2009). Roteiro para classificação de livros: avaliação dos programas de pós-graduação.

http://www.capes.gov.br/images/stories/download/ avaliacao/Roteiro_livros_Trienio2007_2009.pdf

Colciencias (2013). Invitación abierta al proceso de Registro de Editoriales Nacionales 2013.

http://www.colciencias.gov.co/convocatoria/invitaci-n-abiertaal-proceso-de-registro-de-editoriales-nacionales-2013ii 
Cullars, John (1992). "Citation characteristics of monographs in the fine arts". Library quarterly, v. 62, n. 3, pp. 325342.

http://dx.doi.org/10.1086/602473

Cullars, John (1998). "Citation characteristics of Englishlanguage monographs in philosophy". Library \& information science research, v. 20, pp. 41-68.

http://dx.doi.org/10.1016/S0740-8188(98)90005-6

Delgado-López-Cózar, Emilio; Robinson-García, Nicolás; Torres-Salinas, Daniel (2014). "The Google Scholar experiment: how to index false papers and manipulate bibliometric indicators". Journal of the Association for Information Science and Technology, v. 65, n. 3, pp. 446-454.

http://arxiv.org/pdf/1309.2413.pdf

http://dx.doi.org/10.1002/asi.23056

Derricourt, Robin (2012). "Peer review: Fetishes, fallacies, and perceptions". Journal of scholarly publishing, v. 43, n. 2, pp. 137-147.

http://dx.doi.org/10.3138/jsp.43.2.137

Domingo-Baguer, Ignacio (2013). Para qué han servido los libros. Zaragoza: Prensas de la Universidad de Zaragoza. ISBN: 9788415770251

Engels, Tim C.; Ossenblok, Truyken L.; Spruyt, Eric H. (2012). "Changing publication patterns in the social sciences and humanities, 2000-2009". Scientometrics, v. 93, n. 2, pp. 373-390.

https://goo.gl/N5x3ah

http://dx.doi.org/10.1007/s11192-012-0680-2

España (2014). "Resolución de 26 de noviembre de 2014, de la Comisión Nacional Evaluadora de la Actividad Investigadora, por la que se publican los criterios específicos aprobados para cada uno de los campos de evaluación". BOE, n. 290, 1 de diciembre, pp. 98204-98219.

http://www.boe.es/diario_boe/txt.php?id=BOE-A-2014-12482

España (2015). “Real decreto 415/2015, de 29 de mayo, por el que se modifica el Real decreto 1312/2007, de 5 de octubre, por el que se establece la acreditación nacional para el acceso a los cuerpos docentes universitarios". BOE, n. 144, 17 de junio, pp. 50319-50337.

https://www.boe.es/boe/dias/2015/06/17/pdfs/ BOE-A-2015-6705.pdf

Giménez-Toledo, Elea (ed.) (2011). Categorización de publicaciones científicas en ciencias humanas y sociales. Informe. Madrid: EPUC (CSIC).

http://digital.csic.es/handle/10261/89426

Giménez-Toledo, Elea; Fernández-Gómez, Sylvia; Tejada-Artigas, Carlos-Miguel; Mañana-Rodríquez, Jorge (2014). "From book publishers to authors: Information transparency in web sites". Journal of scholarly publishing, v. 46, n. 1, pp. 71-88.

http://dx.doi.org/10.3138/jsp.46.1.004

Giménez-Toledo, Elea; Mañana-Rodríguez, Jorge; Engels, Tim; Ingwersen, Peter; Polonen, Janne; Sivertsen, Gunnar; Verleysen, Frederik; Zuccala, Alesia A. (2015). "The evaluation of scholarly books as research output. Current developments in Europe". In: Procs of the 15 $15^{\text {th }}$ Int l conf of the International Society for Scientometrics and Informe- trics. Istambul: ISSI, 2015.

http://curis.ku.dk/ws/files/141056396/Giminez_Toledo_ etal.pdf

Giménez-Toledo, Elea; Tejada-Artigas, Carlos-Miguel; Mañana-Rodríguez, Jorge. (2013). "Evaluation of scientific books' publishers in social sciences and humanities: Results of a survey". Research evaluation, v. 22, n. 1, pp. 64-77.

http://dx.doi.org/10.1093/reseval/rvs036

Gorraiz, Juan; Purnell, Philip J.; Glänzel, Wolfgang (2013). "Opportunities for and limitations of the Book Citation Index". Journal of the American Society for Information Science and Technology, v. 64, n. 7, pp. 1388-1398.

http://dx.doi.org/10.1002/asi.22875

Grupo de Investigación sobre el Libro Académico (ÍLIA) (2014). Calidad y transparencia informativa en editoriales UNE. Madrid: ILIA (CSIC) [Informe].

http://ilia.cchs.csic.es/SPI/docs/calidad_UNE.pdf

Grupo de Investigación sobre el Libro Académico (ÍLIA) (2015). Calidad y transparencia informativa en editoriales AEM. Madrid: ILIA (CSIC) [Informe].

http://ilia.cchs.csic.es/SPI/docs/calidad_AEM.pdf

Hames, Irene (2008). Peer review and manuscript management in scientific journals: guidelines for good practice. Oxford: Wiley-Blackwell. ISBN: 9781405131599

http://dx.doi.org/10.1002/9780470750803

Hartley, James (2006). "Reading and writing book reviews across the disciplines". Journal of the American Society for Information Science and Technology, v. 57, n. 9, pp. 11941207.

http://dx.doi.org/10.1002/asi.20399

Hicks, Diana; Wouters, Paul; Waltman, Ludo; De-Rijcke, Sarah; Rafols, Ismael (2015). "The Leiden manifesto for research metrics". Nature, n. 520, 22 April, pp. 429-431. http://dx.doi.org/10.1038/520429a

Ingwersen, Peter; Larsen, Birger (2014). "Influence of a performance indicator on Danish research production and citation impact 2000-12". Scientometrics, v. 101, n. 2, pp. 1325-1344.

http://dx.doi.org/10.1007/s11192-014-1291-x

Kousha, Kayvan; Thelwall, Mike (2009). "Google Book search: Citation analysis for social science and the humanities". Journal of the American Society for Information Science and Technology, v. 60, n. 8, pp. 1537-1549.

http://dx.doi.org/10.1002/asi.21085

Kousha, Kayvan; Thelwall, Mike (2015). "An automatic method for extracting citations from Google Books". Journal of the Association for Information Science and Technology, v. 66, n. 2 , pp. 309-320.

http://dx.doi.org/10.1002/asi.23170

Kousha, Kayvan; Thelwall, Mike; Rezaie, Somayeh (2011). "Assessing the citation impact of books: The role of Google Books, Google Scholar, and Scopus". Journal of the American Society for Information Science and Technology, v. 62, n. 11, pp. 2147-2164.

http://dx.doi.org/10.1002/asi.21608 
Mañana-Rodríguez, Jorge (2013). Análisis multidimensional de la especialización en publicaciones de ciencias sociales y humanidades. Tesis doctoral. Madrid: Universidad Carlos III. http://hdl.handle.net/10016/16964

Michavila, Francisco (dir.) (2012). La Universidad española en cifras. Madrid: CRUE.

http://www.crue.org/Publicaciones/Documents/UEC/LA_ UNIVERSIDAD_ESPANOLA_EN_CIFRAS.pdf

Nijkamp, Peter; Rietveld, Piet; Spierdijk, Laura (2000). "Classification techniques in quantitative comparative research: a meta-comparison". In: Reggiani, Aura. Spatial economic science: New frontiers in theory and methodology. Berlin, Heidelberg: Springer, pp. 102-124. ISBN: 9783642 641251 https://ideas.repec.org/p/vua/wpaper/1999-56.html http://dx.doi.org/10.1007/978-3-642-59787-9_7

Research Excellence Framework (REF) [2014]. Assessment framework and guidance on submissions (updated to include addendum published in January 2012). Bristol: Northavon House.

http://www.ref.ac.uk/media/ref/content/pub/ assessmentframeworkandguidanceonsubmissions/GOS\%20 including\%20addendum.pdf

Scopus. Scopus Blog

http://blog.scopus.com/topics/books

Sandstrom, Erik; Sandstrom, Ulf (2009). "Meeting the micro-level challenges: Bibliometrics at the individual level". In: Larsen, B.; Jeta, J. P. Procs of ISSI $2009-12^{\text {th }}$ IntI conf of the International Society for Scientometrics and Informetrics, Rio de Janeiro: Federal University of Rio de Janeiro, v. 2, pp. 846-856.

Sivertsen, Gunnar (2010). "A performance indicator based on complete data for the scientific publication output at research institutions". ISSI newsletter, v. 6, n. 1, pp. 22-28. http://issi-society.org/archives/news/etter21.pdf

Sivertsen, Gunnar (2014). European trends in performance based funding of research institutions [Presentación]. http://www.etag.ee/wp-content/uploads/2014/10/ Sivertsen-Tartu-Nov-2014.pdf

Stern, Madeleine (1983). "Characteristics of the literature of literary scholarship". College and research libraries, v. 44, pp. 199-209.

http://dx.doi.org/10.5860/crl_44_04_199

Testa, James (2012). The book selection process for the Book Citation Index in Web of Science. Philadelphia: Thomson Reuters.

http://wokinfo.com/media/pdf/BKCl-SelectionEssay_web.pdf

Torres-Salinas, Daniel; Delgado-López-Cózar, Emilio (2013) "Cobertura de las editoriales científicas del Book citation index en ciencias sociales y humanidades: ¿la historia se repite?". Anuario ThinkEPI, v. 7, pp. 110-113.

http://recyt.fecyt.es/index.php/ThinkEPI/article/ view/30342

Torres-Salinas, Daniel; Moed, Henk F. (2009). "Library catalog analysis as a tool in studies of social sciences and hu- manities: An exploratory study of published book titles in Economics". Journal of informetrics, v. 3, n. 1, pp. 9-26 http://dx.doi.org/10.1016/j.joi.2008.10.002

Torres-Salinas, Daniel; Robinson-Garcia, Nicolás; JiménezContreras, Evaristo; De-la-Fuente, Enrique (s.d.) "The BiPublishers ranking: Main results and methodological problems when constructing rankings of academic publishers". Revista española de documentación científica [en prensa]. http://arxiv.org/ftp/arxiv/papers/1505/1505.01074.pdf

Torres-Salinas, Daniel; Robinson-García, Nicolás; JiménezContreras, Evaristo; Delgado-López-Cózar, Emilio (2012). "Towards a Book Publishers Citation Reports. First approach using the Book Citation Index". Revista española de documentación científica, v. 35, n. 4, pp. 615-620. http://dx.doi.org/10.3989/redc.2012.4.1010

Van-Leeuwen, Thed (2014). "The meaning of referencing in the humanities and social science and its interpretation in an evaluative context". In: La valutazione della ricerca nelle humanities and social sciences. International workshop organized by Anvur.

Verleysen, Frederik T.; Engels, Tim C. (2013). "A label for peer reviewed books". Journal of the American Society for Information Science and Technology, v. 64, n. 2, pp. 428-430. http://dx.doi.org/10.1002/asi.22836

White, Howard D.; Boell, Sebastian K.; Yu, Hairong; Davis, Mari; Wilson, Concepción S.; Cole, Fletcher T. (2009). “Libcitations: A measure for comparative assessment of book publications in the humanities and social sciences". Journal of the American Society for Information Science and Technology, v. 60, n. 6, pp. 1083-1096.

http://eprints.rclis.org/13120/

http://dx.doi.org/10.1002/asi.21045

Zuccala, Alesia; Guns, Raf (2013). "Comparing book citations in humanities journals to library holdings: Scholarly use versus perceived cultural benefit". In: Gorraiz, Juan; Schiebel, Edgar; Gumpenberger, Christian; Hörlesberger, Marianne; Moed, Henk (Eds.). Procs of ISSI 2013 Vienna: $14^{\text {th }}$ Int/ Society for Scientometrics and Informetrics Conference. Wien: Facultas Verlags- und Buchhandels AG, v. 1, pp. 353-360. ISBN: 9783200031357

http://ebrp.elsevier.com/pdf/2012_Proposal6_Zuccala_Guns.pdf http://www.issi2013.org/Images/ISSI_Proceedings_ Volume_l.pdf

Zuccala, Alesia; Guns, Raf; Cornacchia, Roberto; Bod, Rens (2014). "Can we rank scholarly book publishers? A bibliometric experiment with the field of history". Journal of the Association for Information Science and Technology, v. 66, n. 7, pp. 1333-1347.

http://dx.doi.org/10.1002/asi.23267

Zuccala, Alesia; Van-Leeuwen, Thed (2011). "Book reviews in humanities research evaluations". Journal of the Association for Information Science and Technology, v. 62, n. 10, pp. 1979-1991.

http://dx.doi.org/10.1002/asi.21588

Zuccala, Alesia A.; Verleysen, Frederik T.; Cornacchia, Roberto; Engels, Tim C. (2015). "Altmetrics for the humanities: 
Comparing Goodreads reader ratings with citations to history books". Aslib Journal of information management, v. 67, n. 3, pp. 320-336.

http://dx.doi.org/10.1108/AJIM-11-2014-0152

Unelibros (2014). "Entrevista: Rafael Van Grieken, Director de la Aneca". Unelibros, n. 28, primavera, pp. 8-13.

http://www.une.es/media/Ou1/Image/webmayo2014/

\section{UNElibros\%2028\%20DIG.pdf}

Unelibros (2015). “España crea un sello de calidad para reconocer la excelencia científica del proceso editorial de las colecciones publicadas por las universidades" (2015). Unelibros, n. 30, pp-3-9.

http://www.une.es/media/Ou1/Image/webabril2015/ UNE\%20Libros\%2030\%20DIG.pdf

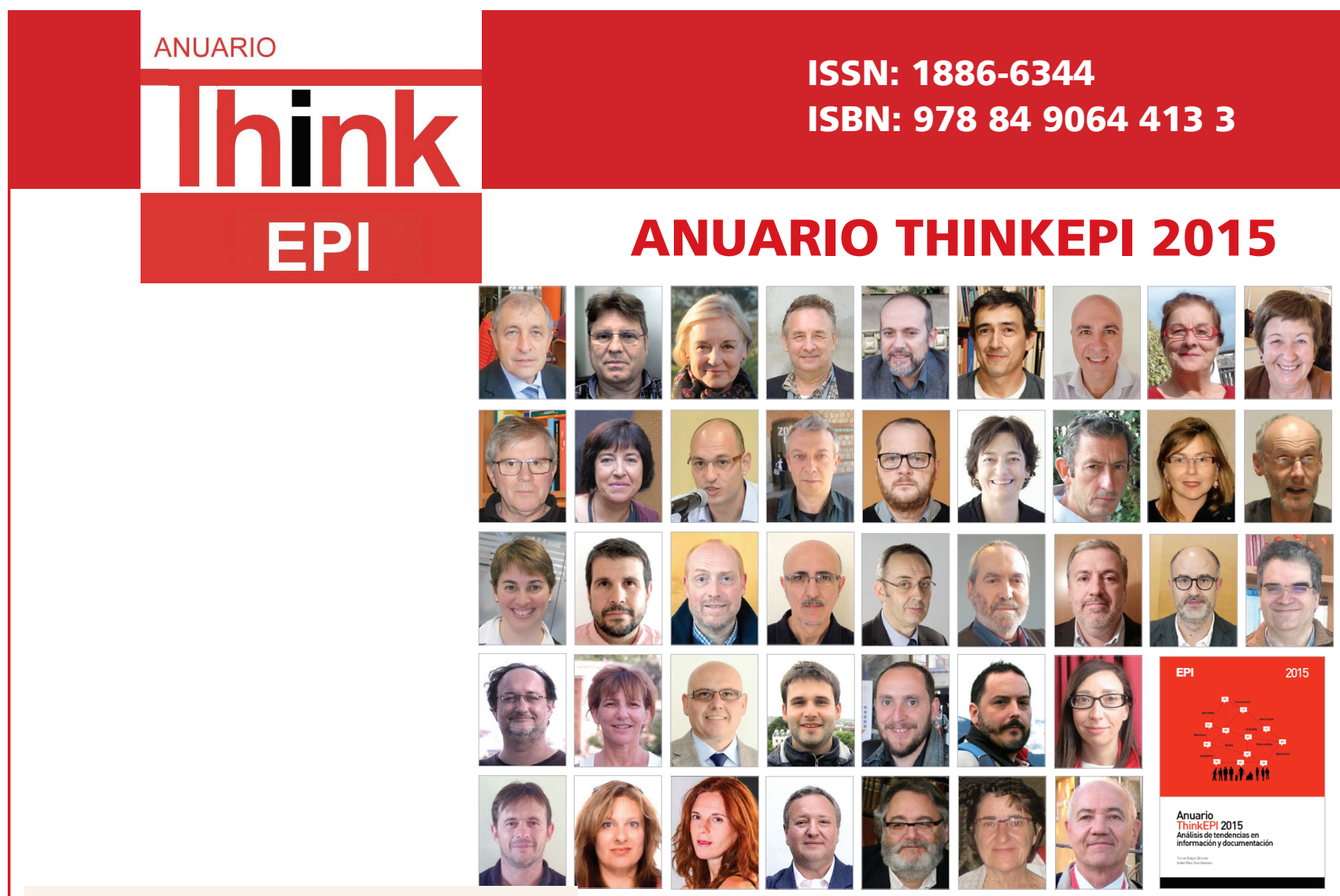

\section{PRECIOS ANUARIO THINKEPI}

Suscripción online (2007-2016) Instituciones $80 €$ Individuos (particulares) $48 €$

Números sueltos

Instituciones

Anuario ThinkEPI 2015 (pdf) $55 €$ Anuario de años anteriores* $30 €$ Individuos (particulares)

Anuario ThinkEPI 2015 (pdf) $30 €$ Anuario de años anteriores* $22 €$
Desde 2014 es posible el acceso mediante suscripción a todos los Anuarios ThinkEPI publicados hasta el momento desde el Recyt de la Fecyt

http://recyt.fecyt.es/index.php/ThinkEPI

$$
\begin{gathered}
\text { Más información: } \\
\text { Isabel Olea } \\
\text { Tf.: } 608491521 \\
\text { epi.iolea@gmail.com }
\end{gathered}
$$

